\title{
APLIKASI METODE OSMOSIS PADA PEMBUATAN SARI BELIMBING WULUH (Averrhoa bilimbi L.) DENGAN TAMBAHAN PEWARNA BUNGA MEXICAN PETUNIA (Ruellia simplex)
}

\author{
The Application of Osmotic Method on Belimbing Wuluh Fruit Juice \\ (Averrhoa bilimbi L.) Using Flower Mexican petunia (Ruellia simplex) \\ as Natural Colorant
}

\author{
Eta Imeida Tiara, Erni Sofia Murtini* \\ Jurusan Teknologi Hasil Pertanian - Fakultas Teknologi Pertanian - Universitas Brawijaya \\ Jl. Veteran, Malang 65145 \\ *Penulis Korespondensi, email: erni.murtini@ub.ac.id
}

\begin{abstract}
ABSTRAK
Belimbing wuluh dapat dimanfaatkan menjadi sari buah dengan metode ekstraksi osmosis. Namun, warna sari buah belimbing wuluh kurang menarik sehingga perlu ditambahkan pewarna alami yang berasal dari bunga Mexican petunia yang mengandung antosianin. Tujuan penelitian adalah untuk mengetahui pengaruh proporsi buah : bunga dan lama osmosis untuk mendapatkan sari buah belimbing wuluh yang baik secara fisik, kimia dan organoleptik. Penelitian menggunakan Rancangan Acak Kelompok (RAK) Faktorial. Faktor I yaitu proporsi buah:bunga (25:1); (25:2); (25:3) dan faktor II yaitu lama osmosis (6, 12, dan 18 jam) dengan 3 kali ulangan. Perlakuan terbaik dilakukan menggunakan metode pembobotan (Zeleny). Perlakuan terbaik ada pada sari buah belimbing wuluh dengan proporsi buah : bunga (25:1) dan lama osmosis 12 jam dengan vitamin C $16,35 \mathrm{mg} / \mathrm{ml}$; antioksidan 57,99 ppm; total gula 9,63\%; nilai kecerahan ( $L^{*}$ ) 48,0 dan nilai kemerahan 14,6. Hasil organoleptik untuk perlakuan terbaik adalah kesukaan warna 2,85 (agak suka); kesukaan rasa 3,075 (agak suka); tingkat kesukaan aroma 2,83 (agak suka); dan tingkat kesukaan kenampakan 2,95 (agak suka)
\end{abstract}

Kata kunci: Belimbing Wuluh; Ekstraksi Osmosis; Mexican petunia; Sari Buah

\begin{abstract}
Belimbing Wuluh is a fruit that has not been fully utilized, so it is necessary to process belimbing wuluh into fruit juice using osmotic extraction. The color of belimbing wuluh juice is less attractive, so Mexican petunia flowers is needed to be added as natural colorant because of anthocyanin content. The purpose of this study are to determine the effect of fruit proportion: flowers and duration of optimal osmotic in order to produce belimbing wuluh juice with good quality. The design experiment used in this research was Randomized Block Design (RAK) Factorial. Factor I is the addition of fruit proportion: flowers (25:1); (25:2); (25:3) and factor II is osmotic time (6, 12, and 18 hours). The best treatment was done using the weighting method (Zeleny). The best belimbing wuluh fruit juice had vitamin C $16,35 \mathrm{mg} / \mathrm{ml}$; antioxidant 57.99 ppm; total sugar $9.63 \%$; brightness value ( $\left.L^{*}\right)$ of 48,0 and redness value of 14.6 . The organoleptic results for the best treatment were color preference 2.85 (slightly like); taste preference 3,075 (slightly like); aroma preference level 2.83 (slightly like); and the level of preference for the appearance is 2.95 (slightly like)
\end{abstract}

Keywords: Belimbing Wuluh, Osmotic Extraction, Mexican petunia, Fruit Juice 


\section{PENDAHULUAN}

Minuman sari buah adalah
minuman yang diperoleh dengan
mencampur air minum, sari buah atau
campuran sari buah yang tidak difermentasi, dengan bagian lain dari satu jenis buah atau lebih, dengan atau tanpa penambahan gula, bahan pangan lainnya, bahan tambahan pangan yang diizinkan (BSN, 2014). Salah satu jenis buah yang berpotensi dijadikan minuman sari buah adalah buah belimbing wuluh (Averrhoa bilimbi Linn). Belimbing wuluh merupakan salah satu buah yang kurang dimanfaatkan. Salah satu penyebabnya adalah rasanya yang sangat asam. Subhadrabandhu (2001) menuliskan bahwa buah belimbing wuluh mengandung beberapa asam diantaranya asam asetat $(1,6-1,9 \mathrm{mEq} / 100 \mathrm{~g})$, asam sitrat (92,6-133,8 mEq/100 g), asam format (0,4-0,9 $\mathrm{mEq} / 100 \mathrm{~g})$, asam laktat $(0,4-1,2 \mathrm{mEq} / 100 \mathrm{~g})$ dan asam oksalat (5,5-8,9 mEq/100 g). Permasalahan lain yang menyebabkan kurangnya pemanfaatan buah belimbing adalah umur simpannya yang pendek (hanya 2-4 hari setelah matang/petik). Seringnya saat berbuah dengan jumlah yang melimpah, karena umur simpannya yang pendek, maka sebagian besar buah dibiarkan jatuh membusuk. Pemanfaatan belimbing wuluh menjadi produk sari buah membuat produk ini dapat disimpan dalam jangka waktu yang lebih lama.

Buah belimbing wuluh potensial diolah menjadi sari buah antara lain karena sari buahnya yang banyak, dan kandungan senyawa bioaktif yang berperan sebagai antioksidan yang dimilikinya. Buah belimbing wuluh matang memiliki kadar air 94,2-94,7\% (Zakaria et al., 2007). Saat buah belimbing wuluh diperas akan didapatkan sari buah sebesar $76,14 \%$. Buah belimbing wuluh juga mengandung vitamin $C 60,95$ $\mathrm{mg} / 100 \mathrm{~g}$ (Lima et al., 2001). Belimbing wuluh mengandung senyawa bioaktif berupa tanin 4,5 g/100 $\mathrm{g}$ (bk) dan proantosianidin 2,2g/100 g, keduanya berperan sebagai antioksidan (Ramsay dan Mueller-Harvey, 2016). Belimbing wuluh juga telah dimanfaatkan sebagai bagian dari pengobatan tradisional (Alhassan dan Ahmed, 2016).

Sari buah belimbing wuluh memiliki warna yang kurang menarik, antara bening putih keruh, sehingga perlu ditambahkan pewarna alami dari bunga Mexican petunia (Ruellia simplex). Bunga Mexican petunia ungu memiliki pigmen berupa antosianin, spesifiknya adalah malvidin (Freyre et al., 2015). Antosianin stabil pada $\mathrm{pH}$ asam dan akan memberikan warna merah sehingga bunga ini akan cocok digabungkan bersama buah belimbing wuluh karena sifat asamnya. Selain warna yang kurang menarik, kenampakan sari buah belimbing wuluh juga keruh sehingga diperlukan metode osmosis untuk mendapatkan sari buah yang jernih. Metode osmosis adalah ekstraksi dengan cara perendaman buah dengan bahan yang memiliki tekanan osmosis lebih tinggi, misalnya sukrosa, sehingga cairan/air buah akan keluar ke media osmosis (Yadav dan Singh, 2014). Pada penelitian ini, proporsi bunga yang ditambahkan dan lama osmosis merupakan hal penting, oleh karena itu penelitian ini mengkaji tentang proporsi buah:bunga dan lama osmosis sehingga dapat memperoleh minuman sari buah belimbing wuluh yang baik.

\section{METODE}

Bahan yang digunakan dalam pembuatan sari buah adalah buah belimbing wuluh, bunga Mexican petunia, gula pasir dan air. Bahan kimia yang digunakan untuk analisis adalah anthrone (Merck), $\mathrm{H}_{2} \mathrm{SO}_{4}$ (Smart Lab), $\mathrm{CaCO}_{3}$ (Merck), aquades, amilum (Merck), asam askorbat (Sigma), KI (Merck), dan I2, etanol 96\% (teknis) dan larutan 1,1-diphynil-2-picrylhdrazil (DPPH) (Sigma) dalam etanol 0,2 mm.

Peralatan yang digunakan dalam pembuatan minuman sari buah belimbing wuluh meliputi kompor gas (Rinnai), kain saring, botol $600 \mathrm{ml}$, saringan plastik, toples plastik, panci stainless steel, termometer $150^{\circ} \mathrm{C}$, dan timbangan digital (Kris Chef). Alat yang digunakan dalam analisis antara lain color reader (Konika Minolta CR-10, Jepang), oven listrik $220 \mathrm{~V}$ (Memmert), desikator (Nalgene), 
texture analyzer (IMADA), spektrofotometer, buret (Herma), timbangan analitik (Mettler Toledo), kompor listrik (Maspion), vortex, $\mathrm{pH}$ meter (Ezido spec: PL $600 \mathrm{~V} 220$ volt), kertas saring, serta glassware pendukung lainnya.

\section{Desain Penelitian}

Penelitian dilakukan bertahap, yaitu penelitian pendahuluan dan penelitian utama. Penelitian pendahuluan dimaksudkan untuk mendapatkan rentang rasio buah dan bunga dan juga lama osmosis. Bunga ditambahkan pada proporsi sampai terjadi tingkat warna sari buah yang berbeda, dan didapatkan proporsi 25:1-25:3 menghasilkan warna sari buah dengan intensitas warna yang berbeda. Lama osmosis dicobakan dengan rentang waktu 3 jam yaitu 3, 6, 9, 12, 15, dan 18 jam. Hasil percobaan menunjukkan bahwa secara organoleptik rasa dan warna dalam rentang 3 jam tidak berbeda, sehingga digunakan rentang penelitian 6, 12, dan 18 jam.

Penelitian utama dilakukan menggunakan metode Rancangan Acak Kelompok (RAK) dua faktor yaitu proporsi buah : bunga yang terdiri dari 3 level yaitu 25:1; 25:2; 25:3 dan lama osmosis yang terdiri dari 3 level yaitu 6 jam, 12 jam dan 18 jam sehingga diperoleh 9 kombinasi perlakuan dengan 3 kali ulangan dan diperoleh 27 satuan percobaan. Data dianalisa dengan menggunakan ANOVA dan diuji lanjut dengan BNT (jika salah satu faktor berpengaruh) dan DMRT (jika terjadi interaksi antar perlakuan) masing-masing dengan $\alpha=0,05$. Pemilihan perlakuan terbaik dengan metode Zeleny. Perlakuan terbaik dibandingkan dengan sari buah kontrol (yaitu sari buah yang diproses dengan memblender buah belimbing, disaring, dan tanpa menggunakan pewarna bunga Mexican petunia) diuji organolpetik dengan Hedonic test. Data disajikan dalam bentuk rata-rata \pm standar deviasi.

\section{Pembuatan sari buah belimbing wuluh}

Buah belimbing matang warna hijau kekuningan dengan ukuran panjang 6$7 \mathrm{~cm}$ dan tidak ada kerusakan fisik digunakan sebagai bahan baku. Bunga Mexican petunia yang digunakan adalah bunga berwarna ungu tanpa kerusakan fisik, dicuci dan diiris tipis ukuran 1-2 mm.
Belimbing wuluh 100 g dicuci, dan dilakukan blansing dengan pengukusan suhu $60 \pm 5{ }^{\circ} \mathrm{C}$ selama 3 menit untuk mencegah perubahan warna dan membuat tekstur menjadi sedikit lebih lunak, lalu diiris dengan ketebalan 1-2 mm. Buah dan bunga dengan rasio $25: 1 ; 25: 2$; dan 25:3 dicampur dengan gula pasir rasio bahan:gula 1:1,25 dalam wadah tertutup, dan didiamkan selama 6, 12, dan 18 jam agar terjadi proses osmosis. Selanjutnya sari belimbing wuluh dan bunga Mexican petunia diekstrak dengan menggunakan penambahan air hangat $45 \pm 5{ }^{\circ} \mathrm{C}$ dengan rasio 1:6. Sari yang didapatkan selanjutnya disaring 2 kali dengan kain saring, dipasteurisasi suhu $80 \pm 3^{\circ} \mathrm{C}$ selama 3 menit, dan dimasukkan dalam botol tertutup rapat sampai dianalisis.

\section{Analisis}

Analisis dilakukan terhadap rendemen ekstrak sari buah yang didapatkan dari proses osmosis dalam waktu yang berbeda. Analisis yang dilakukan pada sari buah belimbing wuluh meliputi uji kimia dan fisik. Analisa kimia yang dilakukan adalah vitamin $\mathrm{C}$ metode titrasi Iiodium (AOAC, 1995), total asam (Ranganna, 1997), analisis aktivitas antioksidan $\mathrm{IC}_{50}$ (Atanassova et al., 2011), total gula metode Anthrone (Apriyantono, 1997), analisis $\mathrm{pH}$ dengan $\mathrm{pH}$ meter (Yuwono dan Susanto, 1998) dan total padatan terlarut (AOAC, 1990). Analisa fisik yang dilakukan adalah viskositas (Yuwono dan Susanto, 1998) dan warna $\left(\mathrm{L}^{*}, \mathrm{a}^{*}, \mathrm{~b}^{*}\right)$ dengan Colour Reader. Analisis juga dilakukan pada bahan baku buah belimbing wuluh dan kestabilan warna ekstrak (antosianin) bunga Mexican petunia. Bunga Mexican petunia diekstrak dengan etanol $96 \% 50 \mathrm{ml}$ yang dicampur dengan asam sitrat hingga pH 3. Ekstrak selanjutnya diuji kestabilannya warnanya terhadap cahaya matahari (dengan dipaparkan lagsung dengan sinar matahari selama 3, 6, dan 9 jam), terhadap suhu (dimasukkan ke dalam oven dengan suhu 20, 40, dan $60^{\circ} \mathrm{C}$ ), dan terhadap pH (bunga Mexican petunia diekstrak dengan $\mathrm{pH}$ berbeda 3, 4, dan 5). 


\section{HASIL DAN PEMBAHASAN}

\section{Karakteristik Bahan Baku Belimbing wuluh}

Buah belimbing wuluh dianalisis vitamin $\mathrm{C}$, total asam, kadar air, $\mathrm{pH}$, tekstur dan warna. Hasil analisa bahan baku buah belimbing wuluh ditunjukkan pada Tabel 1 . Tabel 1 menunjukkan kandungan vitamin $C$ belimbing wuluh cukup tinggi jika dibandingkan dengan kandungan vitamin C pada apel sebesar 5,8 mg/125 g (USDA, 2015). Total asam belimbing wuluh sebesar $1,85 \pm 0,05 \%$ menunjukkan bahwa belimbing wuluh tergolong buah yang masam. Kadar air belimbing wuluh sebesar $90,23 \pm 2,25 \%$, menunjukkan bahwa kandungan air belimbing sangat tinggi. Hal inilah yang membuat belimbing wuluh berpotensi untuk dijadikan minuman sari buah. Derajat keasaman atau $\mathrm{pH}$ belimbing wuluh sebesar $2,2 \pm 0,11$. Hal ini menunjukkan bahwa belimbing wuluh memiliki $\mathrm{pH}$ yang rendah. Tekstur belimbing wuluh sebesar 20,5 $\pm 0,5$ N. Menurut Lima et al. (2001), buah belimbing wuluh yang setengah matang memiliki tekstur yang firm dan menjadi lebih lunak saat belimbing wuluh matang.

\section{Bunga Mexican petunia}

Bunga Mexican petunia dianalisis stabilitas warnanya terhadap cahaya matahari, suhu dan $\mathrm{pH}$ menggunakan color reader. Karakteristik ekstrak bunga Mexican petunia ditunjukkan pada Tabel 2.

Tabel 1. Karakteristik buah belimbing wuluh dibandingkan dengan literatur

\begin{tabular}{lcc}
\hline \multirow{2}{*}{ Parameter } & \multicolumn{2}{c}{ Belimbing Wuluh Segar } \\
\cline { 2 - 3 } & Hasil Analisis & Literatur \\
\hline Vitamin C (mg/100 g) & $20,27 \pm 0,40$ & $25^{\mathrm{a}}$ \\
Total Asam (\%) & $1,85 \pm 0,05$ & $1,93^{\mathrm{b}}$ \\
Kadar Air (\%) & $90,23 \pm 2,25$ & $93^{\mathrm{a}}$ \\
pH & $2,2 \pm 0,11$ & $2,18^{\mathrm{b}}$ \\
Tekstur (N) & $20,5 \pm 0,5$ & - \\
L & $37,43 \pm 3,00$ & - \\
a & $11,23 \pm 2,15$ & - \\
b & $5,26 \pm 0,58$ & - \\
\hline
\end{tabular}

Keterangan :

1. Setiap angka merupakan rerata 3 kali ulangan

2. Angka setelah \pm merupakan standar deviasi dari rerata 3 kali ulangan

a Direktorat Gizi Depkes RI (1996)

b Agustin dan Putri, 2014

Tabel 2. Karakteristik stabilitas warna ekstrak bunga Mexican petunia

\begin{tabular}{ccccc}
\hline \multirow{2}{*}{ Parameter } & & \multicolumn{3}{c}{ Ekstrak Bunga Mexican petunia } \\
\cline { 3 - 5 } & & $\mathbf{L}^{*}$ & $\mathbf{a}^{*}$ & $\mathbf{b}^{*}$ \\
\hline Kontrol & & $25,90 \pm 1,11$ & $47,09 \pm 2,54$ & $7,56 \pm 1,14$ \\
Cahaya Matahari & $3 \mathrm{jam}$ & $27,11 \pm 1,01$ & $43,01 \pm 3,63$ & $9,89 \pm 0,97$ \\
& $6 \mathrm{jam}$ & $29,84 \pm 1,97$ & $38,40 \pm 2,85$ & $10,74 \pm 0,68$ \\
\multirow{3}{*}{ Suhu } & $9 \mathrm{jam}$ & $32,88 \pm 2,65$ & $33,36 \pm 4,66$ & $11,50 \pm 1,78$ \\
& $20^{\circ} \mathrm{C}$ & $24,39 \pm 0,73$ & $49,04 \pm 0,94$ & $1,54 \pm 1,25$ \\
& $40^{\circ} \mathrm{C}$ & $32,44 \pm 3,87$ & $38,93 \pm 2,03$ & $8,08 \pm 1,91$ \\
$\mathbf{p H}$ & $60^{\circ} \mathrm{C}$ & $41,75 \pm 8,11$ & $41,82 \pm 2,61$ & $12,60 \pm 2,25$ \\
& 3 & $25,90 \pm 1,11$ & $47,09 \pm 2,54$ & $7,56 \pm 1,14$ \\
& 4 & $40,46 \pm 4,35$ & $36,08 \pm 3,77$ & $14,07 \pm 2,05$ \\
& 5 & $54,00 \pm 0,98$ & $25,41 \pm 3,22$ & $17,70 \pm 0,60$ \\
\hline
\end{tabular}

Keterangan : kontrol adalah ekstrak bunga tanpa perlakuan 


\section{Rendemen Ekstrak Belimbing Wuluh dan Bunga Mexican petunia}

Pengaruh perlakuan proporsi buah:bunga dan lama osmosis terhadap rendemen ekstrak buah belimbing wuluh dan bunga Mexican petunia ditunjukkan pada Tabel 3. Tabel 3 menunjukkan bahwa semakin banyak bunga yang ditambahkan dan semakin lama osmosis maka nilai rendemen akan semakin tinggi. Tidak hanya belimbing wuluh, namun bunga Mexican petunia segar juga mengandung banyak air, sehingga semakin banyak bahan, semakin banyak cairan/air yang bisa diekstrak. Semakin lama waktu osmosis yang digunakan, bahan akan semakin lama kontak dengan sukrosa sebagai media osmosis sehingga potensi cairan yang terekstrak dari bahan semakin banyak. Semakin lama waktu ekstraksi osmosis maka akan didapatkan hasil yang semakin meningkat karena selama proses osmosis terjadi pergerakan air dari larutan yang memiliki konsentrasi air tingi ke larutan yang memiliki konsentrasi air rendah hingga mencapai keseimbangan. Rendemen tertinggi didapatkan dari perlakuan dengan proses ekstraksi osmosis paling lama 18 jam yaitu sebesar 65,92\%. Namun demikian, jumlah sari yang didapatkan belum maksimum, mengingat menurut Lima et al., (2001), belimbing wuluh adalah buah yang berair tinggi, dan jika buah ini diperas akan dihasilkan sekitar 76,14\%. Belum maksimalnya sari buah yang terkestrak, disebabkan pengecilan ukuran hanya dilakukan dengan pengirisan, sehingga masih menyisahkan sel yang utuh, dan menahan cairan didalamnya, sementara proses osmosis alamiah berjalan lambat.

Tabel 3. Rerata nilai rendemen sari buah belimbing wuluh akibat perbedaan proporsi buah:bunga dan lama osmosis

\begin{tabular}{cccc}
\hline Proporsi Buah : Bunga & Lama Osmosis & Rerata Rendemen (\%) & Notasi \\
\hline $25: 1$ & 6 jam & $28,33 \pm 1,44$ & $\mathrm{a}$ \\
$25: 1$ & 12 jam & $38,64 \pm 0,90$ & $\mathrm{c}$ \\
$25: 1$ & 18 jam & $56,00 \pm 1,63$ & $\mathrm{e}$ \\
$25: 2$ & 6 jam & $30,09 \pm 1,12$ & $\mathrm{a}$ \\
$25: 2$ & 12 jam & $40,75 \pm 0,64$ & $\mathrm{c}$ \\
$25: 2$ & 18 jam & $61,77 \pm 0,79$ & $\mathrm{f}$ \\
$25: 3$ & 6 jam & $33,19 \pm 1,35$ & $\mathrm{~b}$ \\
$25: 3$ & 12 jam & $43,36 \pm 1,09$ & $\mathrm{~d}$ \\
$25: 3$ & 18 jam & $65,92 \pm 1,87$ & $\mathrm{~g}$ \\
\hline
\end{tabular}

Tabel 4. Kandungan vitamin $\mathrm{C}, \mathrm{pH}$, antioksidan, viskositas dan warna sari buah pada proporsi buah:bunga yang berbeda

\begin{tabular}{cccccccc}
\hline $\begin{array}{c}\text { Buah: } \\
\text { bunga }\end{array}$ & $\begin{array}{c}\text { Vitamin C } \\
\mathbf{( m g} /\end{array}$ & $\mathbf{p H}$ & $\begin{array}{c}\text { Antioksidan } \\
\mathbf{1 0 0} \mathbf{~ m p})\end{array}$ & $\begin{array}{c}\text { Viskositas } \\
\mathbf{( c p )}\end{array}$ & $\mathbf{L}^{*}$ & $\mathbf{a}^{*}$ & $\mathbf{b}^{*}$ \\
\hline $25: 1$ & $16,41 \pm$ & $2,59 \pm$ & $59,48 \pm 3,86 \mathrm{~b}$ & $0,098 \pm$ & $47,80 \pm$ & $14,78 \pm$ & $-0,87 \pm$ \\
& $0,85 \mathrm{a}$ & $0,06 \mathrm{c}$ & & $0,001 \mathrm{c}$ & $3,20 \mathrm{a}$ & $1,21 \mathrm{c}$ & $0,38 \mathrm{a}$ \\
$25: 2$ & $14,13 \pm$ & $3,07 \pm$ & $63,72 \pm 5,23 \mathrm{~b}$ & $0,105 \pm$ & $43,84 \pm$ & $16,43 \pm$ & $-1,83 \pm$ \\
& $0,43 \mathrm{~b}$ & $0,07 \mathrm{~b}$ & & $0,001 \mathrm{~b}$ & $2,62 \mathrm{~b}$ & $1,77 \mathrm{~b}$ & $0,60 \mathrm{~b}$ \\
$25: 3$ & $12,69 \pm$ & $3,50 \pm$ & $77,40 \pm 5,40 \mathrm{a}$ & $0,112 \pm$ & $39,31 \pm$ & $20,17 \pm$ & $-2,63 \pm$ \\
& $0,78 \mathrm{c}$ & $0,07 \mathrm{a}$ & & $0,001 \mathrm{a}$ & $2,11 \mathrm{c}$ & $2,94 \mathrm{a}$ & $0,53 \mathrm{c}$ \\
\hline
\end{tabular}

Keterangan: notasi yang sama pada kolom yang sama menunjukkan beda nyata dengan uji BNT $\alpha=5 \%$ 
Jurnal Teknologi Pertanian Vol. 22 No. 2 [Agustus 2021] 139-148

Aplikasi Metode Osmosis Pada Pembuatan Sari Belimbing Wuluh [Murtini dkk]

\section{Karakteristik Sari Buah Belimbing Wuluh}

Perlakuan rasio buah belimbing wuluh:bunga dan lama proses yang berbeda masing-masing memberikan pengaruh yang berbeda terhadap kandungan vitamin $\mathrm{C}, \mathrm{pH}$, antioksidan, viskositas, dan warna $\left(\mathrm{L}^{*}, \mathrm{a}^{*}, \mathrm{~b}^{*}\right)$ sari buah belimbing wuluh yang dihasilkan (Tabel 4 dan 5). Interaksi antar kedua perlakuan memberikan pengaruh pada total asam, total gula dan nilai TPT pada sari buah yang dihasilkan (Tabel 6).

\section{a. Vitamin C}

Semakin besar proporsi bunga yang ditambahkan maka kadar vitamin C semakin menurun. Begitu juga semakin lama proses osmosis kandungan vitamin $\mathrm{C}$ juga semakin menurun. Hal ini dapat disebabkan karena vitamin $\mathrm{C}$ hanya dijumpai di buah belimbing, namun tidak di bunga. Kemungkinan lain adalah karena bunga Mexican petunia berwarna ungu, maka terdapat pikmen antosianin. Menurut
Farr dan Giusti (2018), asam askorbat dapat berinteraksi dengan antosianin pada $\mathrm{C} 4$. Semakin banyak bunga Mexican petunia yang ditambahkan, maka semakin banyak antosianin yang tersedia dan bereaksi dengan vitamin C. Barangkali karena membentuk kompleks itulah, membuat vitamin C tidak terdeteksi dengan uji titrasi yang dilakukan. Kemungkinan berikutnya adalah sifat vitamin $C$ yang tidak stabil, mudah mengalami oksidasi, dan semakin lama osmosis berarti semakin lama kemungkinan vitamin $\mathrm{C}$ terekspos dengan oksigen dan terjadi oksidasi. Menurut Oyetade et al. (2012), stabilitas vitamin C dipengaruhi oleh bahan pengemas, lamanya terekspos dengan udara dan suhu (penyimpanan), terdapat korelasi negatif antara penurunan kandungan vitamin $\mathrm{C}$ dengan waktu (penyimpanan) dan lamanya terpapar dengan udara.

Tabel 5. Kandungan vitamin $\mathrm{C}, \mathrm{pH}$, antioksidan, viskositas dan warna sari buah pada lama proses osmosisi yang berbeda

\begin{tabular}{|c|c|c|c|c|c|c|c|}
\hline $\begin{array}{c}\text { Lama } \\
\text { osmosis } \\
\text { (jam ) }\end{array}$ & $\begin{array}{c}\text { Vitamin } \\
\mathrm{C} \\
(\mathrm{mg} / \\
100 \mathrm{ml})\end{array}$ & $\mathrm{pH}$ & $\begin{array}{c}\text { Antioksidan } \\
(\mathrm{ppm})\end{array}$ & $\begin{array}{l}\text { Viskositas } \\
\text { (cp) }\end{array}$ & $\mathbf{L}^{*}$ & $a^{*}$ & $\mathbf{b}^{*}$ \\
\hline 6 & $\begin{array}{c}16,14 \pm \\
1,16 \mathrm{a}\end{array}$ & $\begin{array}{l}2,89 \pm \\
0,06 \mathrm{c}\end{array}$ & $80,33 \pm 3,97 a$ & $\begin{array}{l}0,103 \pm \\
0,000 \mathrm{c}\end{array}$ & $\begin{array}{c}49,21 \pm \\
3,13 \mathrm{a}\end{array}$ & $\begin{array}{c}15,57 \pm \\
1,67 \mathrm{~b}\end{array}$ & $\begin{array}{l}2,05 \pm \\
0,30 \mathrm{a}\end{array}$ \\
\hline 12 & $\begin{array}{c}14,54 \pm \\
0,45 \mathrm{~b}\end{array}$ & $\begin{array}{l}3,04 \pm \\
0,07 b\end{array}$ & $66,14 \pm 5,20 \mathrm{~b}$ & $\begin{array}{l}0,105 \pm \\
0,001 b\end{array}$ & $\begin{array}{c}43,71 \pm \\
2,87 \mathrm{~b}\end{array}$ & $\begin{array}{c}16,99 \pm \\
1,71 \mathrm{~b}\end{array}$ & $\begin{array}{l}-3,75 \pm \\
0,54 b\end{array}$ \\
\hline 18 & $\begin{array}{c}12,54 \pm \\
0,45 \mathrm{c}\end{array}$ & $\begin{array}{l}3,22 \pm \\
0,07 \mathrm{a}\end{array}$ & $54,14 \pm 5,32 \mathrm{c}$ & $\begin{array}{l}0,107 \pm \\
0,001 \mathrm{a}\end{array}$ & $\begin{array}{c}38,03 \\
\pm 1,93 \mathrm{c}\end{array}$ & $\begin{array}{c}18,80 \pm \\
2,54 \mathrm{a}\end{array}$ & $\begin{array}{c}-3,63 \pm \\
0,66 b\end{array}$ \\
\hline
\end{tabular}

Keterangan: notasi yang sama pada kolom yang sama menunjukkan beda nyata dengan uji BNT a=5\%

Tabel 6. Total asam, total gula dan total padatan terlarut sari buah pada rasio buah:bunga dan lama osmosis yang berbeda

\begin{tabular}{ccccc}
\hline Buah : Bunga & $\begin{array}{c}\text { Lama Osmosis } \\
\text { (jam) }\end{array}$ & Rerata Total Asam (\%) & $\begin{array}{c}\text { Rerata Total } \\
\text { Gula }(\%)\end{array}$ & $\begin{array}{c}\text { Rerata TPT } \\
\left({ }^{\circ} \text { Brix }\right)\end{array}$ \\
\hline $25: 1$ & 6 & $0,80 \pm 0,04 \mathrm{~h}$ & $8,99 \pm 0,34 \mathrm{a}$ & $9,00 \pm 0,20 \mathrm{a}$ \\
$25: 1$ & 12 & $0,71 \pm 0,02 \mathrm{fg}$ & $9,63 \pm 0,42 \mathrm{ab}$ & $9,80 \pm 0,20 \mathrm{~b}$ \\
$25: 1$ & 18 & $0,52 \pm 0,02 \mathrm{c}$ & $10,52 \pm 0,27 \mathrm{c}$ & $10,87 \pm 0,12 \mathrm{~d}$ \\
$25: 2$ & 6 & $0,74 \pm 0,02 \mathrm{gh}$ & $9,95 \pm 0,53 \mathrm{bc}$ & $10,00 \pm 0,20 \mathrm{bc}$ \\
$25: 2$ & 12 & $0,64 \pm 0,02 \mathrm{e}$ & $10,30 \pm 0,65 \mathrm{bc}$ & $11,00 \pm 0,20 \mathrm{de}$ \\
$25: 2$ & 18 & $0,47 \pm 0,02 \mathrm{~b}$ & $12,01 \pm 0,33 \mathrm{~d}$ & $12,87 \pm 0,12 \mathrm{gh}$ \\
$25: 3$ & 6 & $0,69 \pm 0,01 \mathrm{f}$ & $10,51 \pm 0,49 \mathrm{c}$ & $11,60 \pm 0,20 \mathrm{f}$ \\
$25: 3$ & 12 & $0,58 \pm 0,03 \mathrm{~d}$ & $12,34 \pm 0,30 \mathrm{~d}$ & $12,67 \pm 0,12 \mathrm{~g}$ \\
$25: 3$ & 18 & $0,33 \pm 0,02 \mathrm{a}$ & $13,15 \pm 0,27 \mathrm{e}$ & $14,00 \pm 0,20 \mathrm{i}$ \\
\hline
\end{tabular}

Keterangan: notasi yang sama pada kolom yang sama menunjukkan beda nyata dengan uji DMRT $\alpha=5 \%$ 


\section{b. Total Asam}

Kandungan total asam sari buah dipengaruhi oleh interaksi antara proporsi buah:bunga dan lama osmosis. Tabel 6 menunjukkan bahwa semakin banyak bunga petunia yang digunakan dan semakin lama osmosis maka nilai total asam semakin turun. Hal ini dapat terjadi karena komponen asam terdapat di buah belimbing wuluh. Menurut Muzaifa (2018), belimbing wuluh kaya asam organik antara lain asam oksalat, asam askorbat, asam sitrat, asam malat dan asam laktat.

Kadar asam di dalam sari buah akan semakin berkurang dengan semakin lamanya ekstraksi osmosis. Hal ini dapat terjadi karena gula sukrosa memiliki kemampuan dalam mengikat air. Semakin lama ekstraksi dengan osmosis, semakin banyak cairan yang ditarik keluar dari irisan buah belimbing wuluh. Tabel 1 menunjukkan bahwa meskipun belimbing wuluh berasa asam, namun komponen utama terbesar adalah air $(90,23 \%)$. Semakin banyak air yang tertarik keluar dari sel dan selanjutnya menjadi bagian dari sari buah, maka konsentrasi asam menjadi lebih kecil. Rodrigues dan Mauro (2008) menyatakan bahwa gula berperan dalam proses penetrasi sel karena gula mampu meningkatkan tekanan osmotik di dalam sel. Ketika terjadi peningkatan konsentrasi gula di dalam larutan osmosis, maka permeabilitas membran plasma akan mengalami plasmolisis karena adanya perbedaan tekanan osmotik.

\section{c. Derajat Keasaman (pH)}

Semakin banyak bunga Mexican petunia yang digunakan $\mathrm{pH}$ sari buah yang dihasilkan semakin meningkat. Hal ini dapat terjadi karena bunga Mexican petunia memiliki $\mathrm{pH}$ yang lebih tinggi $(4,2)$ dari buah belimbing wuluh $(2,2)$. Nilai $\mathrm{pH}$ berkaitan dengan total asam, data sebelumnya menunjukkan bahwa semakin banyak bunga Mexican petunia yang digunakan total asam sari buah semakin rendah.

$\mathrm{pH}$ sari buah juga dipengaruhi oleh lama osmosis, semakin lama waktu ekstraksi osmosis maka $\mathrm{pH}$ pada sari buah belimbing wuluh semakin naik. Semakin lama proses ektraksi osmosis, dinding sel buah dan bunga akan semakin banyak cairan yang lisis karena adanya perbedaan tekanan osmosis diluar sel. Cairan yang lisis dari sel tidak hanya asam, namun komponen air dan padatan yang terlarut di dalamnya seperti gula, garam mineral dan lainnya yang memiliki $\mathrm{pH}$ yang tidak asam.

\section{d. Total Gula dan TPT}

Total gula dan TPT sari buah belimbing wuluh dipengaruhi oleh interaksi antara proporsi buah:bunga dan lama osmosis (Tabel 6). Semakin banyak bunga yang digunakan, maka akan menyumbang komponen dari bahan yang terekstrak dan terlarut pada sari buah. Saat irisan buah/sayur dimasukkan ke dalam larutan gula dengan konsentrasi tinggi, maka air dan juga komponen terlarut seperti mineral, vitamin dan asam akan mengalir dari buah ke larutan gula (Yadav dan Singh, 2014). Semakin lama proses osmosis semakin banyak total padatan terlarut yang dihasilkan dalam sari buah. Hal ini dapat terjadi karena gula yang digunakan dalam proses ekstraksi adalah dalam bentuk gula pasir/kristal, sehingga diperlukan waktu untuk 'larut' dan membentuk larutan gula dengan osmotik tinggi yang dapat mengeluarkan cairan dari buah. Semakin lama proses, semakin banyak gula yang terlarut dan meningkatkan efektivitas proses osmosis dan tidak menyisahkan gula yang masih dalam bentuk kristal ikut terbuang bersama ampas saat proses penyaringan. Tabel 6 menunjukkan bahwa TPT terbanyak dalam sari buah disumbangkan oleh total gula. Komponen total gula bisa jadi dari sukrosa yang digunakan sebagai media osmosis, ataupun gula yang terdapat baik di dalam belimbing wuluh dan bunga Mexican petunia. Menurut Lima et al. (2001), buah belimbing memiliki total padatan terlarut $5,08^{\circ}$ Brix.

\section{e. Antioksidan}

Pengaruh perlakuan proporsi buah:bunga dan lama osmosis terhadap antioksidan sari buah belimbing wuluh ditunjukkan pada Tabel 4 dan Tabel 5 . Proporsi buah:bunga mempengaruhi 
kandungan $\mathrm{IC}_{50}$ antioksidan. Semakin kecil nilai $\mathrm{ppm}$ antioksidan $\mathrm{IC}_{50}$ menandakan bahwa aktivitas antioksidan lebih tinggi. Namun pada hasil analisis, semakin banyak bunga yang ditambahkan semakin besar nilai ppm antioksidan dimana kekuatan antioksidan sedikit menurun. Antioksidan dalam minuman sari buah belimbing wuluh selain berasal dari bunga Mexican petunia, berasal dari buah belimbing wuluh yang digunakan. Antioksidan yang dominan pada belimbing wuluh adalah vitamin $\mathrm{C}$. Vitamin $C$ berfungsi sebagai antioksidan karena secara efektif menangkap radikal bebas terutama ROS atau senyawa oksigen reaktif (Adawiah et al., 2015). Kenaikan nilai ppm antioksidan (aktivitas antioksidan menurun) dapat dipengaruhi oleh kerusakan antosianin dan adanya oksidasi vitamin C.

Semakin lama osmosis maka kandungan $\mathrm{IC}_{50}$ antioksidan semakin kecil yang menandakan bahwa aktivitas antioksidan lebih tinggi. Hal ini dapat terjadi karena semakin lama waktu ekstraksi osmosis maka lebih banyak senyawa larut air yang akan terekstrak. Vitamin $\mathrm{C}$ dan antosianin merupakan senyawa yang larut di dalam air. Vitamin $C$ merupakan vitamin yang mudah larut dalam air. Senyawa lain lain yang larut di dalam air adalah antosianin yang semakin lama ekstraksi osmosis maka akan semakin banyak kadar antosianin yang terekstrak. Antosianin bersifat larut dalam air dan aman untuk dikonsumsi, sehingga umumnya digunakan sebagai pewarna alami untuk produk makanan dan minuman (Chisté et al., 2010).

\section{f. Viskositas}

Pengaruh perlakuan proporsi buah:bunga dan lama osmosis terhadap viskositas sari buah belimbing wuluh ditunjukkan pada Tabel 4 dan Tabel 5 . Semakin besar proporsi buah:bunga maka nilai viskositas semakin besar. Meningkatnya viskositas pada minuman sari buah belimbing wuluh dapat terjadi karena semakin banyaknya komponen yang terekstrak yang menyebabkan kenaikan pada padatan terlarutnya sehingga viskositas pada minuman sari buah belimbing juga ikut naik. Semakin lama osmosis maka viskositas semakin meningkat. Hal ini dapat terjadi karena semakin lama waktu ekstraksi osmosis maka semakin lama bahan kontak dengan sukrosa yang dapat menyebabkan air dan komponen - komponen organik yang keluar dari bahan semakin banyak. Banyaknya komponen terlarut menyebabkan total padatan terlarut dalam produk semakin tinggi sehingga viskositas produk juga semakin meningkat. Bourne (2002) menuliskan bahwa viskositas dipengaruhi oleh beberapa faktor yaitu suhu, konsentrasi zat terlarut, berat molekul zat terlarut serta padatan tersuspensi. Konsentrasi zat terlarut yang semakin besar dapat meningkatkan viskositas pada suhu yang sama, serta konsentrasi padatan tersuspensi yang larut dalam air seperti gula, garam dan asam memiliki efek pada nilai viskositas produk.

\section{g. Warna $\left(L^{*}, a^{*}, b^{*}\right)$}

Pengaruh perlakuan proporsi buah:bunga dan lama osmosis terhadap nilai kecerahan sari buah belimbing wuluh ditunjukkan pada Tabel 4 dan Tabel 5. Semakin besar proporsi buah:bunga, maka nilai $\left(\mathrm{L}^{*}\right)$ semakin menurun yang menandakan warna minuman yang semakin pekat. Hal ini dapat terjadi karena semakin besar proporsi bunga yang digunakan maka semakin banyak antosianin yang berasal dari bunga Mexican petunia yang ada pada sari buah belimbing wuluh. Antosianin adalah pigmen yang larut dalam air yang menyebabkan warna merah, ungu, dan biru serta banyak ditemukan pada buah dan bsunga. Menurut Freyre et al. (2015), bunga Mexican petunia yang berwarna ungu memiliki total antosianin 86,3 $\mathrm{mg} / \mathrm{g}$ bk dan komponen warna teridentifikasi adalah malvidin 3,5-diglucoside dan malvidin (malonylglucoside)-glucoside. Semakin lama ekstraksi osmosis maka nilai $\left(L^{*}\right)$ semakin menurun. Warna sari buah belimbing pada lama osmosis 18 jam memiliki warna yang lebih gelap dibandingkan dengan lama osmosis 6 jam. Semakin lama proses ekstraksi osmosis maka akan semakin banyak zat yang terkandung di dalam bahan termasuk pigmen larut air yang akan ikut keluar bersama cairan sel yang keluar dari bahan sehingga akan mempengaruhi tingkat kecerahan produk minuman sari buah belimbing wuluh. 
Warna kemerahan $\left(\mathrm{a}^{*}\right)$ juga dipengaruhi proporsi buah:bunga dan lama osmosis, semakin banyak bunga yang digunakan dan semakin lama osmosis maka nilai $\left(a^{*}\right)$ mengalami kenaikan. Warna merah pada minuman sari buah belimbing berasal dari pigmen warna antosianin yang terkandung didalam bunga Mexican petunia. Antosianin bersifat larut air, sehingga dalam proses osmosis, antosianin juga terikut keluar bersama cairan yang terekstrak dari buah dan bunga. Menurut Kidmose et al. (2002), antosianin merupakan senyawa dengan warna merah, biru dan ungu pada buah, sayur maupun tanaman hias.

Warna kekuningan $\left(b^{*}\right)$ sari buah semakin turun dengan meningkatnya proporsi bunga dan lama osmosis (Tabel 4 dan 5). Warna belimbing wuluh hijau kekuningan, namun warna cairannya cenderung jernih-putih, sedangkan bunga Mexican petunia ungu mengandung antosianin yang berwarna ungu kemerahan pada $\mathrm{pH}$ yang asam. Akibat adanya warna ungu kemerahan inilah, maka warna sari buah tidak lagi jernih-putih atau kuning, menjadi lebih ke ungu kemerahan dan semakin ungu-merah gelap dengan meningkatnya jumlah bunga, sehingga nilai kekuningan turun. Jensen et al. (2011) menyatakan Antosianin merupakan komponen bioaktif kelompok flavonoid yang dapat memberikan warna merah, ungu, biru pada bunga, buah dan sayur yang bergantung pada $\mathrm{pH}$ lingkungan tempatnya berada.

\section{Minuman Sari Buah Belimbing Wuluh Perlakuan Terbaik}

Perlakuan terbaik didapatkan dari proporsi buah:bunga 25:1 dan lama osmosis 12 jam (perhitungan tidak ditampilkan). Karakteristik sari buah belimbing wuluh perlakuan terbaik yang dibandingkan dengan kontrol ditunjukkan pada Tabel 7. Data perlakuan terbaik dilakukan perbandingan dengan kontrol yang dilanjutkan dengan Uji T. Sari buah yang digunakan sebagai kontrol adalah buah belimbing yang diolah dengan diblender dan tanpa penggunaan bunga, namun menggunakan gula dan air yang sama dengan perlakuan terbaik. Hasil Uji T yang dilakukan menunjukkan bahwa perlakuan terbaik sari buah belimbing wuluh berbeda nyata dengan kontrol sari buah belimbing wuluh dengan blender tanpa pewarna pada parameter antioksidan, total gula, tingkat kecerahan $\left(\mathrm{L}^{*}\right)$, tingkat kemerahan $\left(a^{*}\right)$ dan tingkat kesukaan sensori warna, rasa, aroma dan kenampakan. Sari buah belimbing yang dihasilkan dengan cara osmosis dengan penambahan bunga Mexican petunia secara organoleptik, rendemen, dan antioksidan lebih baik dibanding kontrol.

\section{SIMPULAN}

Proporsi buah : bunga berpengaruh nyata $(\alpha=0,05)$ terhadap rendemen, vitamin $\mathrm{C}$, total asam, $\mathrm{pH}$, antioksidan, total gula, total padatan terlarut, viskositas, nilai kecerahan $\left(L^{*}\right)$, nilai kemerahan $\left(a^{*}\right)$, nilai kekuningan $\left(b^{*}\right)$ dan seluruh parameter organoleptik sari buah belimbing wuluh. Perlakuan terbaik berdasarkan Multiple Atribute Zeleny ada pada sari buah belimbing wuluh dengan proporsi buah:bunga (25:1) dan lama osmosis 12 jam dengan vitamin $\mathrm{C}$ sebesar $16,35 \mathrm{mg} / \mathrm{ml}$; antioksidan sebesar $57,99 \mathrm{ppm}$; total gula sebesar $9,63 \%$; nilai kecerahan $\left(L^{*}\right)$ sebesar 48,0; nilai kemerahan sebesar 14,6; kesukaan warna 2,85 (agak suka); kesukaan rasa 3,075 (agak suka); tingkat kesukaan aroma 2,83 (agak suka); dan tingkat kesukaan kenampakan 2,95 (agak suka).

\section{DAFTAR PUSTAKA}

Adawiah, Sukandar, -D., Muawanah, -A., 2015. Aktivitas antioksidan dan kandungan komponen bioaktif sari buah namnam. Jurnal Kimia Valensi. 1, 130-136. https://doi.org/10.15408/jkv.v0i0.3155

Alhassan, A, -M., Ahmed, Q, -U., 2016. Averrhoa bilimbi Linn.: A review of its ethnomedicinal uses, phytochemistry, and pharmacology. Journal of Pharmacy and Bioallied Sciences. 8, 265271. https://doi.org/10.4103/09757406.199342

AOAC, 1990. Official methods of analysis, 16th ed. AOAC International, Washington DC

AOAC, 1995. Official methods of analysis, 
Jurnal Teknologi Pertanian Vol. 22 No. 2 [Agustus 2021] 139-148

Aplikasi Metode Osmosis Pada Pembuatan Sari Belimbing Wuluh [Murtini dkk]

16th ed. AOAC International, Washington DC

Apriyantono, AD. 1997. Petunjuk Laboratorium Analisa Pangan. IPB, Bogor

Atanassova, -M., Georgieva, -S., Ivancheva, -K., 2011. Total phenolic and total flavonoid contents, antioxidant capacity and biological contaminants in medicinal herbs. Journal of the University of Chemical Technology and Metallurgy. 46, 81-88. https://dl.uctm.edu/journal/node /j2011-1/12_Maria_Atanasova.pdf

Bourne, MC. 2002. Food, Texture and Viscosity: Concept and Measurement. Academic Press, London

BSN, 2014. SNI 3719:2014 - Minuman Sari Buah. Badan Standardisasi Nasional (BSN), Jakarta

Chisté, R, -C., Lopes, A, -S., de Faria, L, J, G., 2010. Thermal and light degradation kinetics of anthocyanin extracts from mangosteen peel (Garcinia mangostana L.). International Journal of Food Science Technology. 45, 1902-1908. https://doi.org/10.1111/j.13652621.2010.02351.x

Farr, J, -E, Giusti, M, -M, 2018. Investigating the interaction of ascorbic acid with anthocyanins and pyranoanthocyanins. Molecules. 23, 744. https://doi.org/10.3390/molecules23040744

Freyre, -R., Uzdevenes, -C., Gu, -L., Quesenberry, K, -H., 2015. Genetics and anthocyanin analysis of flower color in Mexican petunia. Journal of the American Society for Horticultural Science. 140,45-49. https://doi.org/10.21273/JASHS.140.1.45

Jensen, M, -B., Bergamo, C, A, L, -D., Payet, R, -M., Liu, -X., Konczak, -I., 2011. Influence of copigment derived from Tasmannia pepper leaf on Davidson's plum anthocyanins. Journal of Food Science. 76, 447-453. https://doi.org/10.1111/j.17503841.2011.02077.x

Kidmose, U, Edelenbos, M, Nørbæk, R, Christensen, L, P. 2002. 'Colour stability in vegetables'. Dalam DB MacDougall (Ed.). Colour in Food. Woodhead Publishing Limited

Lima, V, L, A, -G. De, Mélo, E, D, -A., Lima, L, D, S., 2001. Physicochemical characteristics of bilimbi (Averrhoa bilimbi). Revista Brasileira de Fruticultura. 23, 421-
423. https://doi.org/10.1590/s010029452001000200045

Muzaifa, -M., 2018. Perubahan komponen kimia belimbing wuluh (Averrhoa bilimbi L.) selama pembuatan asam sunti. Jurnal Teknologi Pertanian Andalas. 22, 37-43. https://doi.org/10.25077/jtpa.22.1.3743.2018

Oyetade, O, -A., Oyeleke, G, -O., Adegoke, B, -M., Akintunde, A, -O., 2012. Stability studies on ascorbic acid (vitamin C) from different sources. IOSR Journal of Applied Chemistry. 2, 20-24. https://doi.org/10.9790/5736-0242024

Ramsay, -A., Mueller-Harvey, -I., 2016. Procyanidins from Averrhoa bilimbi fruits and leaves. Journal of Food Composition and Analysis. 47, 16-20. https://doi.org/10.1016/j.jfca.2015.12.004

Ranganna, S. 1997. Manual of Analysis of Fruit and Vegetable Product. Tata Mcgraw Hill Publishing Co. Ltd., New Delhi

Rodrigues, A, -E., Mauro, M, -A., 2008. Effective diffusion coefficients behavior in osmotic dehydration of apple slices considering shrinking and local concentration dependence. Journal of Food Process Engineering. 31, 207-228. https://doi.org/10.1111/j.17454530.2007.00148.x

Subhadrabandhu, S. 2001. Under-utilized tropical fruit of Thailand. Food and Agricultural Organization of The United Nations (FAO) Regional Office of Asia and The Pacific, Bangkok

USDA, 2015. USDA National Nutrient Database for Standard Reference. Nutrients: Vitamin C, total ascorbic acid (mg)

Yadav, A, -K., Singh, S, -V., 2014. Osmotic dehydration of fruits and vegetables: a review. Journal of Food Science and Technology. 51, 1654-1673. https://doi.org/10.1007/s13197-012-0659-2

Yuwono, SS, Susanto, T. 1998. Pengujian Fisik Pangan. Universitas Brawijaya, Malang

Zakaria, Z, -A., Zaiton, -H., Henie, E, F, -P., Jais, A, M, -M., Zainuddin, E, N, H, -E., 2007. In vitro antibacterial activity of Averrhoa bilimbi L. leaves and fruits extracts. International Journal of Tropical Medicine. 2(3), 96-100. https://medwelljournals.com/abstract /?doi=ijtmed.2007.96.100 